\title{
The Global Governance of Maritime Piracy
}

\author{
Otello Campanelli
}

Published online: 6 October 2012

(C) CEEUN 2012

\begin{abstract}
Within less than a decade piracy has been turned from a marginal economic problem into a global security problem. The effective governance of piracy represents a vital need for the international community. Two aspects of this governance are particularly important and are broadly highlighted in the present work: a prescriptive type of governance, or how piracy should be disciplined according to international law, and a descriptive kind of governance, concerning what is rather than what should be, which is closely linked to international relations dynamics. For an effective management—and solution —of the piracy problem, it is underlined how there are obstacles of both legal and practical natures, but that these, in conclusion, may be surmounted by the presence of a major State willingness to act. The governance of piracy is still more and more influenced by momentary interests and by geopolitical dynamics, than by the actual dimension and dangerousness of modern day pirates. International law evolves slowly in a rapidly changing world, and the overlapping regime covering piracy may represent a barrier to the solution of the issue because it does not comprise a coherent and comprehensive anti-piracy regime.
\end{abstract}

Keywords Maritime piracy - UNCLOS (or Law of the Sea) - Somalia - Security

\section{Introduction}

Modern maritime piracy represents a considerably complex problem because it has many interconnections and poses several challenges for global governance. Piracy has posed a threat to all states' maritime interests for nearly as long as people have sailed the oceans (Rubin 1988; Haywood 2011). States have long recognised the

O. Campanelli $(\bowtie)$

University of Rome "Tor Vergata", Rome, Italy

e-mail: otellocampanelli@yahoo.it 
threat that piracy poses to political and commercial interests, as well as to human safety.

The latest IMO Annual Report (MSC.4/Circ.180 1 March 2012), concerning 2011, states that the number of acts of piracy and armed robbery against ships, which were reported to the Organization to have occurred or to have been attempted in 2011, was 544 , an increase of 55 (11.3\%) over the figure for 2010. From the Report, it emerges that the areas most affected in 2011, as in 2010, were East Africa and the Far East, in particular the South China Sea, followed by the Indian Ocean, West Africa, South America and the Caribbean. The majority of incidents occurred off East Africa, and these have increased from 172 in 2010 to 223 in 2011, thus returning to the same level as in 2009 (222 incidents). As a consequence of the deployment of mother ships by Somali pirates and the increased range of their operations, the number of incidents occurring in the Arabian Sea increased from 16 in 2010 to 28 in 2011. However, the number of incidents in the Indian Ocean decreased from 77 to 63 in 2011. Despite the high number of Somalia-based piracy attacks, the success rate has been significantly reduced. Somali pirates attacked 172 ships in 2010 and hijacked 50 of them while in 2011 out of 286 attacks only 33 resulted in the ship being hijacked (success ratio $11.5 \%$ ). In addition, the total number of incidents of piracy and armed robbery against ships, reported to have occurred or to have been attempted from 1984 to the end of December 2011, has risen to 6,260.

In the past few years, given this considerable increase in pirate attacks and the growing concerns regarding ships becoming targets of instruments for terrorist attacks, the States' efforts to eradicate these crimes do not seem to have attained their goals. Considering the grave danger to life and the serious risks to navigational safety and the environment which attacks by pirates may cause, the United Nations Security Council has adopted, under the provisions of chapter VII of the Charter of the United Nations, Resolutions 1918 (2010), 1950 (2010), 1976 (2011), 2015 (2011) and 2020 (2011) in relation to piracy and armed robbery in waters off the coast of Somalia. However, the main source for the discipline of piracy is constituted by the United Nations Convention on the Law of the Sea (UNCLOS, also called Convention of Montego Bay) of 1982. In addition, there are several different layers of obligations and authorities that arise from UNCLOS, the International Maritime Organisation, international human rights law, security regimes, anti-terrorism treaties, and freedom of seas doctrine. Because of the damage that maritime piracy inflicts on international trade and general safety, it has long been treated as a universal crime whose perpetrators were subject to punishment by any State that apprehended them.

Alongside piracy, which has always been one of the major threats to navigation, crimes related to terrorism have attracted progressively more attention, particularly since 9/11. A ship may indeed be a target for pirates as well as an instrument for destruction in the hands of terrorists, causing death and critical damage to nearby ships, port infrastructures and the environment. Given these risks, the reactions of individual States and of the international community as a whole have gone in two distinct directions: on the one hand, towards the adoption of pre-emptive measures and, on the other, towards the provision of repressive measures (such as allowing States to intervene against those responsible for the acts of violence at sea). 


\section{The Rules of the Game}

The international community, in an attempt to govern the disturbing (mostly economically) phenomenon of piracy, has given itself a series of norms. A wellknown fact is that in the international community there is no superior entity, which may impose laws on its members; States must give themselves rules in order to regulate their pacific coexistence. Piracy embraces several different aspects of international life, starting from the regulation concerning the law of the sea, passing through the concept of State sovereignty and ending in the contrast to crimes against the international community. This coexistence of multiple interests has had repercussions on the legal framework of piracy. The governance of piracy appears immediately complicated, paradoxically, by the norms which were created to manage it. Several Conventions which complement each other but, at the same time, overlap on certain aspects generate further confusion regarding the powers and jurisdictions of the States. This is even truer nowadays, in that the evolutions in real world have not yet been followed by parallel changes in the relevant norms. It is therefore essential to examine the juridical shortcomings in the governance of maritime piracy.

Firstly, it is necessary to comprehend the importance of distinguishing between the territorial sea and the high seas, since repressive powers attributed to the States vary on the basis of the area of sea in which the crime is committed. In the territorial sea, the coastal State is recognised vast powers, and may even exercise its criminal jurisdiction on board a foreign ship passing through the territorial sea if the crime is of a kind to disturb the peace of the country or the good order of the territorial sea (article 27 UNCLOS). Such powers are recognised by the United Nations Convention on the Law of the Sea so to preserve the coastal State's interests and not to eradicate crimes considered prejudicial for the entire international community (Leanza 1999). Further proof of this reasoning is the fact that it is the coastal State's legal system that must define the criminal conducts; with the obvious consequence that what constitutes a crime for one State is not necessarily considered as such in another.

In the high seas, on the contrary, no State may validly purport to subject any part of the high seas to its sovereignty (art. 89 UNCLOS). The high seas are open to all States (art. 87) and every State, whether coastal or land-locked, has the right to sail ships flying its flag on the high seas (art. 90). The principle of the freedom of the high seas implies that, in general, ships that are on the high seas are subject to the exclusive jurisdiction of the State of their flag. Ships in this part of the sea are even considered, by part of the literature, "islands of a nation's territory outside its primary borders" (Kontorovich 2004). However, in order to effectively reach the freedom of the high seas, it is necessary that the security in this area is not compromised. That is why the UNCLOS provides for any State's power to intervene against private ships suspected of committing particular crimes, which are peremptorily indicated by the Convention. This power acts independently from the nationality of the ships. Flag State jurisdiction thus moves back and leaves space for the universal jurisdiction, justified by the need for repressing unlawful acts 
considered by custom as international crimes able to produce serious detriment to the whole international community (also known as delicti juris gentium).

Secondly, as has been extensively underlined (Wiener 1979; Thomas 2004; Brignardello 2010), the definition of piracy represents a limit to the fight against it. The definition is constraining and not updated; therefore, it does not fully describe piracy's evolution and its current characteristics.

Although the nations throughout the world have long accepted that piracy is an international crime, there has been no universal acceptance of what constitutes piracy (Wiener 1979). The term "piracy", indeed, transcends easy labelling. Piracy has one meaning in the insurance industry, another in criminal law, another in international law, another in the international shipping industry and yet another in the "common law". Therefore, there are no less than five reasonable interpretations of the word "piracy" and the context of the wording may determine its meaning (Passman 2009). These differences are found in conventional and customary international law, national law and a range of commercial contracts and there is no necessary harmony to be found in the various sources (Thomas 2004). The necessary starting point is the traditional piracy juris gentium, defined and disciplined, progressively, from the Declaration of Paris in 1856 to the Convention of Geneva in 1958 and ending with the Montego Bay Convention in 1982 (UNCLOS).

The Convention of Montego Bay, after stating that the State parties are required to cooperate to the fullest possible extent in the repression of piracy on the high seas or in any other place outside the jurisdiction of any State (art. 100), confers to each State the power, carried out by warships (art. 107), of seizing a pirate ship or aircraft, or a ship or aircraft taken by piracy and under the control of pirates, and arrest the persons and seize the property on board (art. 105). These powers are quite extensive, but they are limited to where there are acts of violence that correspond to the definition of piracy juris gentium as given by article 101: “(a) any illegal acts of violence or detention, or any act of depredation, committed for private ends by the crew or the passengers of a private ship or a private aircraft, and directed: (1) on the high seas, against another ship or aircraft, or against persons or property on board such ship or aircraft; (2) against a ship, aircraft, persons or property in a place outside the jurisdiction of any State; (b) any act of voluntary participation in the operation of a ship or of an aircraft with knowledge of facts making it a pirate ship or aircraft; (c) any act of inciting or of intentionally facilitating an act described in subparagraph (a) or (b)". There are thus specific requisites for an act of piracy. It must be an act of violence committed by the crew or passengers, it must be committed for private ends, it must involve two ships and it must occur on the high seas.

This UNCLOS norm has been subject to various criticisms (Ronzitti 1983). Firstly, requiring for piracy to be "illegal" implies that there must be, curiously enough, a "legal" form of piracy. Secondly, the notion of "private ends" would exclude (and it would be an important exclusion) all acts committed for lato sensu political ends, including terrorist acts (Grimaldi 2003). By the way, it is questionable whether "private ends" only includes "profit making ends" or whether it may be interpreted extensively so to comprise private but not profit making ends (as, for example, an act committed for vengeance). 
Apart from the several interpretative problems arising from this notion, it seems evident that, by requiring the afore-mentioned conditions, the effective possibility for States to act is in reality quite narrow. As a result, mutiny, hijacking by people already on board, acts of violence aimed at the seizure of the ship for political or terrorist reasons are not considered piracy (Sico 1999; Scovazzi 2004; Angeloni and Senese 2005). Towards ships which are on the high seas and which commit crimes that are different from those defined in article 101 only the flag State may, according to article 92.1, exercise coercive powers or may authorize third States to intervene. The natural reluctance of certain States in giving their consent ends up by favouring criminals who are in the meantime aware of the potential benefits of operating under more tolerant flags, or those of States which are simply unable to react (Beyers 2004; Torresi 2007).

The previous analysis underlines the need for a comprehensive legal discipline for the atypical expressions of piracy (i.e. "armed robbery at sea" when not conducted in the high seas and linked, more recently, with terrorism) because "there are numerous types of attacks on ships, not all of which fall within the various definitions of piracy in the relevant codes, agreements and legislation" (Collins and Hassan 2009). A similar discipline is not present in the UNCLOS, which only focuses on the minimal traditional notion of piracy. This opens up a significant series of problems in the repression of the crime. Acts of piracy carried out in the territorial sea remain excluded from the UNCLOS normative (the repression is here left to the coastal State, in respect of its sovereignty). In addition, foreign warships may not pursue and capture pirates who find shelter in the territorial sea of coastal States without their authorisation.

In relation to these last facts, it is undoubtedly interesting to note that, according to the International Maritime Organisation's data, almost two-thirds of acts of violence occur in the territorial sea and in internal waters, and these do not, as a result, fall into the category of international piracy and are thus not subject to the regime of universal jurisdiction (Tancredi 2008).

With the aim of overcoming these inconveniences, various solutions have been suggested. One part of the literature suggests to apply, by analogy, the norms on piracy to all other crimes committed in the territorial sea (Sandiford 1966; Ronzitti 1983; Ciciriello 1988; Pocar 2009); another one recalls some articles from the UNCLOS and deduces implicitly, on the one hand, a prohibition for any act of violence in the high seas (Witschel 2008; Wolfrum 2008) and, on the other, the possibility for any state to adopt repressive measures. It is even argued that piracy may be regulated by the New York Convention on transnational organised crime (Keyuan 2000), or by the SUA Convention of 1988 and its 1995 Protocol (Collins and Hassan 2009). Apart from these attempts, which do not seem to have encountered significant success, the UNCLOS convention appears still an inadequate instrument for the repression of such a vast array of violent acts (augmented by the terrorist threat) at sea. Except for the narrow possibility of piracy, any intervention is tied to the flag State's authorisation.

In the third place, piracy is complicated even under another aspect. In order to repress a crime, capturing the people responsible for it is not enough, but it must be avoided that the guilty party is released without being adequately taken to trial. If 
laws ensuring the prevention and prosecution of piracy are not in place, no amounts of ships or weapons will be effective enough to discourage piracy (Blanco-Bazàn 2009; Gould 2010). On this matter, the Convention only specifies that the courts of the State which carried out the seizure may decide upon the penalties to be imposed, and may also determine the action to be taken with regard to the ships, aircraft or property, subject to the rights of third parties acting in good faith (art. 105). There is, as a result, a risk that the State which captures the pirates in the high seas does not possess, in its legal system, the right penalty for such a crime, or does not have any interest in adjudicating pirates that attacked foreign ships (Kontorovich 2004; Csonka 2009), maybe fearing retaliation and threats from criminal organisations: "we see everyday that warships refuse to engage with pirates unless they are attacking ships flying their same flag" (Blanco-Bazàn 2009). It is important to proceed in a refinement of structures and processes related to persecution and prosecution of piracy, but it also may be argued that rather than lacking sufficient domestic legislation there might in reality be a reduced political will to prosecute pirates.

A recent IMO Resolution (A.1044(27), 20 December 2011) stresses the need for all States to have in place a comprehensive legal regime to prosecute pirates, consistent with international law. The State must take all necessary legislative, judicial and law-enforcement action so as to be able, subject to national law, to receive, prosecute or extradite any pirates or suspected pirates including those who illicitly finance, plan, organize, or unlawfully profit from pirate attacks off the coast of Somalia, including the Gulf of Aden and the western Indian Ocean area, as well as armed robbers captured by naval vessels or military aircraft, or other ships or aircraft clearly marked and identifiable as being on government service. It may be noted that on this matter there is a significant distance between what is prescribed and what is actually done: "universal jurisdiction over pirates was more a matter of theory than of practice" since "very few criminal prosecutions for piracy can be found that depended on the universal principle" (Kontorovich 2004).

\section{The International Relations of Piracy}

After having analysed the norms that the actors of the international community have given themselves to discipline piracy, and after having examined the effectiveness of these norms, it is of vital importance to change the point of view. The legal framework, or the prescriptive aspect, should be counterbalanced by a more pragmatic, or descriptive, investigation on the global governance of piracy. Why, apart from the afore-mentioned legal factors, have the States' efforts to eradicate these crimes not attained their goals? It is essential to investigate the possible existence of practical obstacles and international relations dynamics that impede the fight against piracy (Chalk 1998; Johnson and Pladdet 2003; Liss 2003; Chalk 2008).

The previous description of the differences between the territorial sea and the high seas may open up to interesting remarks on the evolution of State sovereignty and the law of the sea. On a more theoretical basis, sovereignty has historically had 
its foundations directly tied to notions of territoriality (Benton 2009). It is obvious, then, that issues of governance beyond the boundaries of a nation-state pose challenges on matters pertaining to sovereignty, transnational governance and enforcement of international law. On the one hand, there are cases of piracy occurring along the coasts of States (fully sovereign) that clearly do not do enough to fight this crime. On the other hand, piracy takes place off the coasts of States that are simply not capable of doing anything (States in critical situations, failed States).

First of all, it is interesting to note that the fact that most attacks occur while a ship is in port or anchored in adjacent the territorial sea raises several questions. Apart from the legal aspect of not representing the traditional form of piracy, this fact is intimately tied to the effective policing and territorial control carried out by coastal States. As already mentioned, acts of violence that occur in the territorial sea remain under the jurisdiction of the coastal sovereign State. Given the difficulty in policing extensive coastlines (like in Southeast Asia), it may be stated that, in some cases, the coastal States may have little or no interest in fighting piracy in their territory. Some experts even argue that it is likely that some of the maritime security forces may be often complicit in these crimes, especially in areas where a culture of corruption (possibly boosted by underpaid maritime security forces or smuggling activities) has evolved under years of authoritarian governments, often abetted by the military (Dillon 2000; Mo 2002; Barrios 2005; Young 2007; Reale 2011).

Securitisation (established by the Copenhagen School of Security Studies led by Buzan, Waever and De Wilde), or militarisation, has proven to be a relevant factor in fighting piracy. When States have concentrated their enforcement resources at a particular place and a particular time, significant results have been achieved, as happened in 2005 and 2006 when Singapore, Malaysia and Indonesia cracked down on pirates following the designation of the Malacca Strait as a war zone by Lloyd's of London (Ong-Webb 2006; Bahar 2007; Teo 2008).

Furthermore, it is evident that "la capacité des Etats à lutter contre la piraterie est non seulement dépendente de la volonté politique de voir appliquer le droit, mais aussi des moyens matériels et humains mis à disposition des forces de police pour lutter contre les pirates" (Polere 2005). It is possible to hypothesize that the recent flare-up of such an old phenomenon (as old as maritime navigation itself) may be greatly caused by the lack of political power in coastal States, often tied to critical economical conditions which may be, in some cases, even partly originated by the many errors in "decolonisation" (Dani 2011, and postcolonial theory literature).

There are States that do not possess the instruments or the strength (or the will) to intervene (as they should) in order to guarantee the respect for legality in their areas (sometimes called "Failed States") (Rice 2008; Hastings 2009; Ronzitti 2008). Especially since 9/11, research on State failure has attempted to distinguish weak States from failed States (Rotberg 2002; Menkhaus 2003; Lambach 2004). The distinction is important because there is some question as to which is better for illicit groups such as pirates, terrorists, insurgents, and organised criminals (Cutter et al. 2003; Menkhaus 2004; Innes 2007; Watts et al. 2007; Murphy 2009).

Since pirate attacks occur at sea, sometimes outside the jurisdiction of any State at all, the connection of pirates to land is less obvious than for terrorists and other criminals. The literature on piracy acknowledges the importance of physical 
geography, cultural acceptance, and weak or corrupt State institutions for the promotion of attacks and the provision of pirate safe havens (Ong-Webb 2007; Murphy 2008), as well as the role of corrupt or otherwise friendly local officials as well as market infrastructure in countries such as China, India, Iran in the disposal of hijacked ships and cargo (Abhyankar 1998; Murphy 2007). The physical landscape matters as well, which is why pirates in general are drawn to certain areas of the world (Murphy 2008). Many incidents take place in or near narrow, congested channels that serve as chokepoints for world commerce, such as the Bab al-Mandab at the southern tip of the Red Sea, and the Phillips and Singapore Straits at the southern terminus of the Strait of Malacca in Southeast Asia. In such places, ships must slow down to navigate through shallow waters and underwater obstacles, as well as avoid other ships, leaving them open to attack by land-based pirates.

In this context, it must be underlined that the Resolution 1816/2008 of the United Nations Security Council allowed-for the first time-the pursuit (that must have started in the high seas) to continue inside the Somali territorial sea. The intervention by the Security Council was intended for the coordinated activities of the NATO and UE "Atalanta" missions, even providing for the possibility of capturing pirates directly on Somali territory (in order to eliminate the pirates' headquarters, Resolution 1851/2008). This provision is considered as an exception and does not represent a potential transformation in the concept of sovereignty, as IMO [in Resolution A.1044(27), 20 December 2011] recalled: "reiterating its full respect for the sovereignty, sovereign rights, jurisdiction and territorial integrity of Somalia and the relevant provisions of international law, in particular UNCLOS". The fact that no intervention has been carried out on the basis of these two Resolutions, neither in the Somali territorial sea nor on Somali territory, shows that no State has been willing to engage in such a delicate and politically unstable reality.

From a strictly operative point of view, piracy repression forces encounter a significant limitation in the circumstance that warships must not enter (contrarily to what occurs in Somalia by virtue of the United Nations Security Council Resolutions) in the Yemenite territorial sea, which can, as a result, be a safe haven for pirates.

As far as the potential worrisome connections with terrorism are concerned (Abhyankar 2004; Ong 2004; Murphy 2007; Lehr 2007; Oriolo 2009), Somalia represents an emblematic example of the consequences of failed States and piracy (Brignardello 2009; Koskenmaki 2004; Telesca 2009; Ciciriello, Mucci 2010). Most pirate attacks off the coasts of Somalia seem to present the conditions for the classical notion of piracy (as defined by UNCLOS: occurring in the high seas, for private ends and involving two ships), but it can nevertheless be argued that the political and economic background in the Somali State opens the door to disturbing hypotheses of connivances and criminal ties (especially between pirates and the Somali Islamic movement Al-Shabaab, which some experts claim to be tied with Al-Qaida). The criminal organisations that are involved in modern piracy do not use their profits in Somalia, leaving the State in this critical condition. The profits made with piracy are transferred elsewhere and reinvested in other activities, may them be unlawful or (apparently) lawful. Part of the literature explicitly mentions a transnational criminal network with headquarters, other than in Somalia, in Kenia, 
Dubai, Lebanon and other countries, and warns against the fact that piracy operations may become a new dangerous channel for funding terrorist organisations (Reale 2011). IMO [in the afore-mentioned Resolution, A.1044(27), 20 December 2011] has made clear that one of the priorities is to "investigate and prosecute those who illicitly finance, plan, organize, or unlawfully profit from pirate attacks off the coast of Somalia, including the Gulf of Aden and the western Indian Ocean area".

It is argued that the attempted linkage of Somali piracy to transnational terrorist networks is likely to enable some transformations in international norms regarding how non-state actors are conceptualized and dealt with (Heinze and Steele 2009). Piracy already challenges modern norms against non-state violence in the international system, yet this new permutation is likely to allow international governmental actors greater leeway in violating territorial sovereignty in pursuit of individuals or non-state groups (see the works of Wight and Bull, where they argue the existence of room for non-state actors, even the Somali pirates, in their "international society" approach).

Pirates have often tried justifying their activity by stating that their legitimate fishing activities along the Somalian coast, their only source of income, was impeded by the modern fishing ships of developed countries, or that Somali waters were used as dumps for toxic wastes. What is certainly true is that a merely repressive approach to piracy is not sufficient (Thomson 1996; Pocar 2009). Part of the literature explicitly mentions a link between piracy and economic and financial crisis (Dillon 2000). The economic factor is indeed very relevant in piracy. The three components of maritime industry most affected by it are the shippers (manufacturers that own the cargo), carriers (companies that own the vessels), and insurers of the ships and cargoes. In the highly competitive shipping market, the carriers often decide not to report incidents of piracy. They prefer to cover the losses out of their own resources rather than pay increased insurance costs after placing a claim or incurring delays due to an official investigation. With many pirate attacks going unreported, calculating the amount of financial damage caused by this maritime crime is very difficult.

A correct approach would undoubtedly focus on State-building and State capacity, especially if we view pirates as primarily economically-motivated actors, and on assisting States to build capacity in piracy-infested regions of the world to deter, interdict and bring to justice those who commit acts of piracy and armed robbery against ships.

\section{Conclusion}

In conclusion, the governance of maritime piracy appears more and more influenced by momentary interests and by geopolitical dynamics, than by the actual dimension and dangerousness of modern day pirates.

The international community and the individual States possess the instruments (both legally and operatively) to fight this crime. The factors examined previously show that there is no concretely uncontrollable element related to piracy, apart from the hypothetical link to terrorist activities. 
As a result, as far as global governance is concerned, piracy may be considered a non-problem, in that it is the absence of willingness to eradicate piracy by the States that determines the current situation. The juridical shortcomings may be seen as a consequence and as a symbol of this unwillingness, not as its cause.

The overlapping of different regimes and, most of all, normative fragmentation represents one obstacle towards an effective global governance of maritime piracy. This is even truer if we consider that the borders between the different crimes are becoming less clear all the time, and that piracy (characterised by the pursuit of private ends) may not always be easily distinguished from other crimes driven by politics or terrorism.

Furthermore, the accession of a noteworthy number of States to the Conventions is not sufficient, but it is necessary that these states implement the provisions. As a matter of fact, States have proven up to today not very willing to intervene against criminal ships of a different nationality, not having any interest in capturing pirates and in taking them to trial, and it may be observed that "the universal right to establish jurisdiction sometimes seems to work against the aim of ensuring that pirates do not escape prosecution" (Blanco-Bazàn 2009; Kraska 2011).

The attention of the international maritime community is equally focused, on the one hand, on piracy juris gentium as defined by article 101 UNCLOS and, on the other, on acts of "armed robbery" defined as "any unlawful act of violence and detention or any act of depredation, or threat thereof, other than an act of 'piracy', directed against a ship or against persons or property on board such ship, within a State's jurisdiction over such offences" [IMO Resolution A.922(22)]. This issue has obvious consequences on the governance of the phenomenon, as it is further intimately intertwined with questions of sovereignty and repression of the crimes.

\section{References}

Abhyankar J (1998) Maritime fraud and piracy. Transnational Organised Crime, vol 4

Abhyankar J (2004) Piracy and armed robbery and terrorism at sea. ORF Workshop on Maritime Counter Terrorism, New Delhi

Angeloni M, Senese A (2005) Diritto del mare e contrasto ai traffici illeciti internazionali. Cacucci, Bari

Bahar M (2007) Attaining optimal deterrence at sea: a legal and strategic theory for naval antipiracy operations. Vanderbilt J Transnatl Law 40:1-85

Barrios E (2005) Casting a wider net: addressing the maritime piracy problem in Southeast Asia. Boston Coll Int Comp Law Rev 28:149-163

Benton L (2009) A search for sovereignty: law and geography in European empires, 1400-1900. Cambridge University Press, New York

Beyers M (2004) Policing the high seas: the proliferation security initiative. Am J Int Law 98(3):526-545

Blanco-Bazàn A (2009) War against piracy? Some misconceptions and oversights in the repression of crimes at sea. Diritto marittimo, p 267

Brignardello M (2009) I poteri degli Stati nella repressione della pirateria: il fallimento dello "Stato" somalo. Aviat Marit J 1:14

Brignardello M (2010) Nozione di pirateria e sue implicazioni. Studi in onore di Francesco Berlingieri, Genova, pp 224-246

Chalk P (1998) Low intensity conflict in Southeast Asia: piracy, drug trafficking, and political terrorism. Conflict Issues 305/306 (January-February)

Chalk P (2008) The maritime dimension of international security terrorism, piracy, and challenges for the United States. RAND, Santa Monica 
Ciciriello MC (1988) Pirateria (diritto internazionale). In: Enciclopedia giuridica, vol 23, p 1

Ciciriello MC, Mucci F (2010) La moderna pirateria al largo delle coste della Somalia: un banco di prova per vecchi e nuovi strumenti internazionali di prevenzione e repressione. Rivista del Diritto della Navigazione 39:87-106

Collins R, Hassan D (2009) Applications and shortcomings of the Law of the Sea in combating Piracy: a South East Asian perspective. J Marit Law Commer 40:1

Csonka P (2009) Briefing on international piracy. Piracy and armed robbery against shipping. http://ec.europa.eu/transport/maritime/events/

Cutter SL, Richardson DB, Wilbanks TJ (2003) The geographical dimensions of terrorism. Routledge, New York

Dani A (2011) Pirateria: fenomeno antico e problemi recenti. In: La Torre U, Sia ALM (eds) La sicurezza nel trasporto e nelle infrastrutture della navigazione marittima ed aerea. Rubbettino, Catanzaro, pp $97-113$

Dillon D (2000) Piracy in Asia: a growing barrier to maritime trade. Heritage Foundation Report, 1379

Gould H (2010) The legacy of punishment in international law. Palgrave Macmillan, New York

Grimaldi F (2003) Il fenomeno del terrorismo: riflessi sul trasporto marittimo. Diritto Marittimo, p 1066

Hastings J (2009) Geographies of state failure and sophistication in maritime piracy hijackings. Political Geogr 28(4):213-223

Haywood R (2011) Maritime piracy. Routledge, New York

Heinze E, Steele B (2009) Ethics, authority and war: non-state actors and the just war tradition. Palgrave Macmillan, New York

Innes MA (2007) Denial of sanctuary: understanding terrorist safe havens. Praeger Security International, Westport

Johnson D, Pladdet E (2003) An overview of current concerns in piracy studies and new directions for research. People and the sea II: conflict, threats, and opportunities. International Institute for Asian Studies and the Centre for Maritime research, Amsterdam

Keyuan Z (2000) Enforcing the law of piracy in the South China Sea. J Marit Law Commer, pp 107-117

Kontorovich E (2004) The piracy analogy: modern universal jurisdiction's hollow foundation. Harv Int Law J 45(1):183-237

Koskenmaki R (2004) Legal implications resulting from State failure in light of the case of Somalia. Nordic J Int Law 73:1-36

Kraska J (2011) Contemporary maritime piracy: international law, strategy, and diplomacy at sea. Praeger, Santa Barbara

Lambach D (2004) The perils of weakness: failed states and perceptions of threats in Europe and Australia. New security agendas: European and Australian perspectives conference. Menzies Center, King's College, London

Leanza U (1999) Il diritto degli spazi internazionali. Le nuove frontiere, Giappichelli

Lehr P (2007) Violence at sea: piracy in the age of global terrorism. Routledge, New York

Liss C (2003) Maritime piracy in Southeast Asia. Contemporary Southeast Asian Studies, p 63

Menkhaus K (2003) Quasi-states, nation building and terrorist safe havens. J Confl Stud 23:7-23

Menkhaus K (2004) Somalia: state collapse and the threat of terrorism. Oxford University Press, Oxford

Mo J (2002) Options to combat maritime piracy in Southeast Asia. Ocean Dev Int Law 33(3-4):343-358. doi: $10.1080 / 00908320290054819$

Murphy MN (2007) Contemporary piracy and maritime terrorism. International Institute of Strategic Studies, London

Murphy MN (2008) Piracy and the exploitation of sanctuary. In: Norwitz JH (ed) Armed groups: studies in national security, counterterrorism and counterinsurgency. United States Naval War College, Newport

Murphy MN (2009) Small boats, weak states, dirty money: the challenge of piracy. Columbia University Press, New York

Ong GG (2004) "Ships can be dangerous too": coupling piracy and maritime terrorism in Southeast Asia's maritime security framework. Institute of Southeast Asian Studies, Singapore

Ong-Webb GG (2006) Piracy, maritime terrorism and securing the Malacca straits. Institute of South East Asian studies, Singapore

Ong-Webb GG (2007) Piracy in maritime Asia: current trends. In: Lehr P (ed) Violence at sea: piracy in the age of global terrorism. Routledge, New York

Oriolo A (2009) Pirateria, terrorismo e sicurezza dei mari nella nuova politica marittima comunitaria. In: Del Vecchio A (ed) La politica marittima comunitaria. Aracne, Rome, pp 113-139 
Passman MH (2009) Interpreting sea piracy clauses in marine insurance contracts. J Marit Law Commer 40:59-79

Pocar F (2009) Per sradicare il fenomeno necessario coinvolgere gli Stati della regione. Guida al Diritto, Il Sole 24 Ore, vol 19, p 11

Polere P (2005) La piraterie maritime aujourd'hui. Le Droit Maritime Français 659:307-404

Reale G (2011) La pirateria marittima: evoluzione del fenomeno criminale ed efficacia attuale degli strumenti di contrasto disponibili. In: Reale G (ed) Il contrasto alle attività illecite in mare. Edizioni Scientifiche Italiane, Napoli, pp 13-77

Rice X (2008) Focus: ocean terror. How savage pirates reign on the world's high seas. The Observer, England, vol 27

Ronzitti N (1983) Pirateria (diritto vigente). Enciclopedia del diritto 33:916

Ronzitti N (2008) La lotta alla pirateria al largo delle coste della Somalia e nell'Oceano Indiano. Osservatorio di Politica Internazionale 44:1-15

Rotberg R (2002) The new nature of nation-state failure. Wash Q 25:85-96

Rubin A (1988) The law of piracy. Naval War College Press, Newport

Sandiford R (1966) Pirateria. In: Noviss. Dig. It., Torino, vol 13, p 109

Scovazzi T (2004) La sicurezza della navigazione marittima. Profili di diritto internazionale. In: Zanelli (ed) Inquinamento del mare e sicurezza della navigazione. Edizioni Scientifiche, Napoli

Sico L (1999) L'alto mare. Giappichelli, Torino

Tancredi (2008) Di pirati e Stati “falliti”: il Consiglio di sicurezza autorizza il ricorso all'uso della forza nelle acque territoriali della Somalia. Rivista di Diritto Internazionale, p 937

Telesca C (2009) Recenti misure internazionali di contrasto alla pirateria. Rivista di Diritto dell'Economia, dei Trasporti e dell'Ambiente 7:1-20

Teo CH (2008) Asia's evolving security architecture and the role of the US. Speech by the Singaporean Minister of Defence, Washington DC

Thomas R (2004) Insuring the risk of maritime piracy. J Int Marit Law 4:345

Thomson J (1996) Mercenaries, pirates and sovereigns. Princeton University Press, Princeton

Torresi FM (2007) La pirateria marittima del XXI secolo. Il Diritto Marittimo, p 598

Watts C, Shapiro J, Brown V (2007) Al-Qaida's (mis)adventures in the Horn of Africa. Combating Terrorism Center, United States Military Academy, West Point

Wiener A (1979) Piracy: the current crime. Lloyd's Marit Commer Law Q 4:469-484

Witschel G (2008) Mare liberum and maritime security: contradiction or complement? In: Nordquist MH, Wolfrum R, Norton Moore J (eds) Legal challenges in maritime security. Martinus Nijhoff, LeidenBoston

Wolfrum R (2008) Fighting terrorism at sea: options and limitations under international law. In: Nordquist MH, Wolfrum R, Norton Moore J (eds) Legal challenges in maritime security. Martinus Nijhoff, Leiden-Boston

Young A (2007) Contemporary maritime piracy in Southeast Asia: history, causes and remedies. Institute of Southeast Asian Studies, Singapore 